\title{
Social Reproduction in K-12: Life-long Effects on Middle-class Students
}

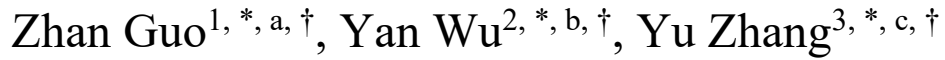 \\ 1 University of Washington 98105 WA, US. \\ ${ }^{2}$ University of Georgia 30602 GA, US \\ ${ }^{3}$ Michigan State University 448824, MI, US. \\ ${ }^{*}$ Corresponding author.Email: ${ }^{a}$ guozhan4@uw.edu, ${ }^{b} y w 92978 @ u g a . e d u,{ }^{c}$ Zhan1281@msu.edu \\ ${ }^{\dagger}$ These authors contributed equally.
}

\begin{abstract}
The educational system plays an essential role in people's lives, while it may not provide equitable opportunities for students. This paper has two main themes. The first is associating with the social reproduction theory of cultural theorist Pierre Bourdieu; more specifically, it is about the social reproduction theory applied in the educational system. Social reproduction emerged to be invisible in the educational field, but we discovered that there is an interaction and operation of various forms of social reproduction and different capitals, which is directly relevant to the students involved in acquiring growth through teaching. While most people receive some form of education, their educational level is ultimately determined by social reproduction. In addition, this article demonstrated three capitals in the article: financial capital, social capital, and human capital. Social capital relates to a resource that is granted by a person's social position. Students can take advantage of their social capital by leveraging their social networks to receive a better education. Financial capital shows inequities in education that can be perceived from the perspectives of the personal, the school, and society, all of which impact a person's education. Due to the differences in individuals' knowledge and skills, the education level they attain would vary. Meanwhile, the human capital of their families would play a role in their education and future career success. This article mainly focuses on how social reproduction influences K-12 students, notably middle-class students.
\end{abstract}

Keywords: Social reproduction, Social Capital, Financial Capital, Human Capital.

\section{INTRODUCTION}

The reproduction of social inequities through generations is known as social reproduction. By reproduction, it means the rich elements of society or the poor elements of society replicate themselves across generations. People with affluent parents grow up to be wealthy, while those with poor parents grow to be poor. The majority of the social reproduction process is made up of three factors. These factors will aid us in gaining a better understanding of social reproduction. They are financial capital, social capital, and human capital. Social reproduction is particularly relevant to the research of how schooling works in the social reproduction theory [1].

$\mathrm{K}-12$ is the abbreviation of pre-school education to high school education, which is now commonly used to refer to basic education. In China, the range for K-12 is from Kindergarten (usually 5-6 years old) to Grade 12 (usually 17-18 years old). The 3-year-old student will attend three year's kindergarten. The 6-year-old student will attend six year's elementary school. The 12-year-old student will attend three years of junior high school. The number " 12 " represents 12 grades and 12 years of study. $\mathrm{K}-12$ plays an essential and profound role in a student's life. It is the best time for students to construct their cognitive development. Students are responsible for their own success and their parents' and family's futures. Accordingly, accepting K-12 education and getting a high-quality K-12 education has a significant impact on one's ability to succeed in the future. Educational advantage may lead to occupational attainment: higher education, comprising institution and topic of study, includes cognitive growth, private and selected secondary schools, school-level qualifications [2]. 
Social reproduction is important for understanding the relations between individuals, groups, and society in education. The emergence of social reproduction has significantly extended the development of education. Based on social reproduction theory, schools are not institutions providing equal opportunities for people. Instead, they are mechanisms for perpetuating social inequalities [3]. Moreover, educational institutions provide unequal resources and give students disproportionate opportunities based on their social capital, which further perpetuates social inequalities [3].

Maintaining the law of the social cycle and hierarchy in society is common in the social reproduction process. On the other hand, the current education system aggravates inequality in social capital and makes it more visible. Education helps us to see inequality in social reproduction. Education works as a mediator between social origins and high social class destinations [2]. Meanwhile, social reproduction aids in the detection of educational inequity. As people know the correlation between social reproduction and the education system, they can improve the current education system to affect social reproduction and then reduce overall inequality in the long run. When people introduce the education system into the social reproduction process, education could be a double-edged sword. It can be the breakthrough to eliminate inequality while it may reinforce social stratification at the same time.

Indeed, the correlation between social reproduction and education is not a new concept in the field. There are researches about its effects either on students in schools or adults after graduation. Many things in the K-12 actually reinforce and further perpetuate social reproduction, which affects people's performance or outcome at school [4]. For instance, testing, high-stakes testing specifically, reproduces social and educational inequality [5]. Investing in informal education is beneficial for children's human capital, alleviating social reproduction [6]. There is also research about certain populations like China's second-generation rural-tourban migrant youth who do not have urban residential status and suffer from the loss of higher education opportunities [7]. It indicates that the local government, setting the residential status system, reproduces social hierarchy [7].

From the aspect of effects after graduation, migrant youth can only provide cheap labor forces for manufacturing and low-skilled service industries due to the system, which blocks their way upward in terms of social status mobility [7]. Inequality caused by uneven educational resource distribution is common worldwide, further perpetuating social reproduction and limiting students' upward mobility [8]. Students' social capital, determined by social reproduction, affects their career choices when they graduated [9]. Even till mid-life, education, largely determined by social reproduction or social origin, affects people's top social class destination [2]. In the professional field, education would even amplify formal social capital, which leads to the success of ventures' founders and therefore perpetuates social reproduction [10].

While many researchers have already discussed how social reproduction is being reinforced by the educational system or the other way around, most of them did not draw attention to how the correlation between social reproduction affects people generally in the long run. This paper would be discussed two aspects: effects revealing in K-12 schools and after graduation. The main goal of this paper is to discuss how the correlation between social reproduction and education, especially K12, leads to life-long effects on middle-class people generally.

\section{MIDDLE-CLASS SOCIAL REPRODUCTION}

Pierre Bourdieu, the cultural theorist, defined the social class as the "interplay and operation of various forms of capital, within the set of durable and objective relations in which the classes subject is located" [11]. Due to the differences in social classes or capitals, children would receive different education in various qualities, affecting their chances of success as they move into adulthood. Within those various forms of capital, there are social capital, financial capital, and human capital.

There is much debate over the definition of social capital. It can be a process, a resource, or capital [12]. In this paper, social capital is defined as the link or social networks people are in. The paper, therefore, provides more detail about the advantages that social capital brings to the student. Financial capital is the accumulation of wealth [13]. In other words, financial capital is money or assets people own, which is quite straightforward. Lastly, human capital is considered "as the individual capabilities, knowledge, skills, experience and problemsolving abilities that reside in people in an organization" [14]. Basically, human capital is defined as the ability or skills owned by individuals or groups. This paper will discuss the life-long effects on people caused by those three capitals in education.

Since people's chances of success would be affected by all the capital, their upward social mobility is accordingly changed. Also, that process will repeatedly happen over generations. In this case, the repeating process is social reproduction. While it sounds like it is a structural advantage for the middle class, compared with the working class, it still requires people from the middle class to act strategically, or they would still lose the privileged status across generations [15]. They must activate the resources they get from their families or communities to make use of them. As it is getting more 
competitive to get into excellent colleges and maintain their privileges, middle-class parents are more stressed than ever [16].

Even though some may consider social reproduction a unique thing in certain countries, many pieces of research already showed that it is common across the world. It is common in western countries like the United Kingdom and in eastern countries like China [16, 17]. While middle-class families in the United Kingdom and China share the same anxiety and pressure, China has a unique system, consisting of danwei (work unit) and hukou (household registration), that produces extra challenges for people to move upward [17]. Despite challenges brought up by social reproduction that can be varied across countries, it is a consensus that capital one has would play a negligible role in one's education, affecting one's social reproduction and leading to lifelong effects.

\subsection{Social Capital}

Social capital is a significant integrative notation for expressing how self-interested individuals engage in collective behaviors and keep social order in place [18]. Social capital is one of the important sections of social reproduction, and social capital is closely related to our life. The concept of social capital has been a powerful idea in social science. Moreover, social capital exists in the structure of interpersonal relationships. Another study implies social capital is positively correlated with action success. If a person is in a favorable starting position, this person could access and use social capital resources more effectively.

Social capital has been "accepted" in practically every field that deals with human behavior, including pedagogy, social work, social anthropology, history, and health sciences, among others [19]. On top of that, we could see the diversity of social capital phenomena involved in our lives. Furthermore, we believe that social capital significantly impacts academics, particularly because there is a long-term effect between $\mathrm{K}-12$ students. Social capital represents the relationship between each student and society to have a clearer understanding of their social connection to help students find their own social capital relations and obligations. Extending consequence in a bigger picture, social capital has an advantageous effect for the K-12 student. A simple fact currently social capital normally comes from the social relationship between people and society. Social capital makes each one of us united and makes us better as a society. From a macro point of view, social capital has an advantageous effect on K-12 students. A simple fact is that social capital allows students to understand their connection to society to find a suitable social group and understand their obligations and responsibilities as a group. In this way, students can make friends that are suitable for themselves and feel they don't need to experience the difference from others in the same social responsibility to form a sense of gap. This concept can also make students feel confident in their studies to help students grow better.

When students were in kindergarten level, they might not realize social capital or how it could have a long-life effect. But social capital has already affected some of the children's behaviors. Such as starting at the elementary level, children are more willing to play with people of the same social class. Retrospectively, social capital is imperceptibly influenced in early childhood education. By applying social capital theory into education, the rich social capital resources student's network of associations can find resources and essential forms of social support, which means when a student has a better social capital resource, a student could obtain more learning opportunities and acquire more advantage of study [20]. In contrast to human capital and financial capital, social capital has gradually become a resource for the K-12 middle-class parents in the educational system. More middle-class parents realize the benefits of social capital as a tool and applied by middle-class parents to guarantee the reproduction of their status in society by offering a decent education for their children [19]. In education, social capital has also played another significant part. For instance, with the occurring importance of social capital in the educational system, social capital has also played a significant influence. For example, consider the fact of social capital in the educational system. That might indicate education is no longer solely determined through a student's innate factor and acquired ability. It is making each student much more dependent on their social network. The long-term effect for K-12 students is that the educational system might provide education inequality for the student. A parent's social class could determine the student's education; the child's greatest level of education is determined by the parents' social class level [21]. Basically, social classes offer unfair resources to parents for them to cooperate with teacher requests for parental participation [22].

In conclusion, social capital, school achievement, and school attainment are all positively related to and important for student academic performance [21]. In the field of K-12 education, social capital is an indispensable factor. While social capital exists, we need to ensure the fairness of educational equity for the student. Furthermore, the benefit for students who received benefits from social capital could be more likely 1) go into college after graduating from high school, 2) lower dropout rate 3) involved in community and society [23]. Therefore, we have reason to believe that their social capital theory has a long-life effect on K-12 middle-class students. 


\subsection{Financial Capital}

Financial capital refers to the financial resources that individuals, businesses, and governments have to meet their needs. Individuals, for example, spend it to acquire essentials [24]. Financial capital is an important factor in determining your social position, such as whether you are affluent or poor and if your family is middle-class or working-class. Another important feature of financial capital is that you can invest in something and get some returns. From the financial capital factor, the article below will talk about how financial capital effect education from the angle of personal, school, and society separately.

From a personal aspect, financial capital reveals inequality in learning resources among students. The wealthy people have a lot of resources called financial capital. When compared to them, the middle or working class has less. Low-income families spend less on their children's education than wealthy families do. Furthermore, this chasm widens the divide between the available educational resources to students at home after school. Most institutions choose to start an online lesson for their students during the pandemic last year. As we all know, access to an online class requires a stable internet connection and a readily available technological device. However, some low-income families do not have a laptop or any other device for which their child can complete the online course. This is especially evident among lowincome families in grades K-12. After-school reading about picture books is also a wonderful example of the disparity between students' learning resources that financial capital offers.

From the school's perspective, financial capital widens the gap between schools. A school's initial establishment and subsequent maintenance development require financial resources. The school's software and hardware facilities demonstrate the school's distinction. Better software and technology cannot exist without the financial capital to support them, such as better-trained instructors, a school library, and so on. There are fewer resources and opportunities in High Poverty Schools. As a result, financial capital widens the difference between schools and has an impact on student performance. It seems that the dollars allocated to instruction do have some relationship with student achievement [25]. From the standpoint of schooling, urban school systems frequently include large proportions of underperforming students from low-income families [26]. Furthermore, the quality of the teachers demonstrates the disparity between schools. Financial capital has an impact on professor quality. Professors with advanced degrees are attracted by higher salaries and a pleasant working atmosphere.

Financial capital exacerbates the disparity in educational opportunities between affluent and poor students and long-term impacts students' careers. When students have the same school performance and grade during the K-12 schooling period, a family's financial resources determine what kind of school they can attend. For example, for two students with the same test grade, one attends public school while the other attends a private school because her family can afford the higher school tuition. After graduation, this disparity will continue to have an impact on a student's career. Some schools have the financial resources to establish a consulting department, which focuses on major choice and career advice. In addition, many employers use degrees to screen applicants. If you graduate from a high-ranked and well-known university, you will undoubtedly get a significant advantage in the admissions process. As a result, financial capital has a long-term impact on a person's life, including their K-12 education and their post-university employment.

To sum up, the impact of financial capital on education can be viewed from various perspectives. Financial capital, on the other hand, reflects the inequalities that present in schooling. Different financial resources imply a person's ability to access various educational resources. Its financial resources influence the quality of a school. In addition, having more financial resources means that a student will have more educational opportunities. All of them will impact the rest of a person's life, whether directly or indirectly. The inequity that comes with financial resources will have a long-term impact on a person's K-12 education.

\subsection{Human Capital}

Human capital, generally considered as the ability or skills one has, is one of the capitals that plays an important role in one's education and future [14]. This paper defines skills or knowledge adults utilize as resources to support their children in schools and help them succeed later. When one's parents or families own human capital, there is a higher chance that they can help their children to reach a better student outcome or grade, which is a part of human capital. For instance, parents who can speak a second foreign language like French can help their children to study French. However, parents who can only speak one language may not be able to help their children as much as those who can speak French did. Attaining higher education with help and support from well-educated adults, middle and upper-class students can accumulate human capital faster and more efficiently. Therefore, human capital definitely plays an essential role in students' accumulation of human capital at schools. Nevertheless, the effects of human capital do not simply disappear once students graduated. Middle-class families utilize their own human capital to help their children to attain a better and higher education. As a result, their children would gain human capital from being well-educated. It is a circle of social reproduction, 
which makes descendants of middle and upper-class families maintain their social status.

After students graduated, the accumulated human capital would have life-long effects on them, their families, and even countries. From their own success, studies showed that human capital would affect their career choices and entrepreneurship. Based on a research of colonial Benin, Leonard and his found "a significant positive treatment effect of education for the first generation of students, as well as their descendants" [27]. They would live a better life and are less likely to be farmers. Their relatives and descendants benefit from their human capital as well, so the family would move upward in terms of social class. Additionally, several studies indicate that human capital, accumulated by getting higher education, can help individuals earn more and then benefit the whole country's economy [28-30]. Besides that, human capital can help with one's entrepreneurship. Martin and his fellow researchers claimed that entrepreneurship education, increasing students' human capital, can help students to reach a better entrepreneurship outcome [31]. According to the other research, entrepreneurs' human capital can support them in making business decisions and seize great opportunities, which make them successful in the end [32]. Therefore, it is obvious that human capital can help with personal success.

What's more, gaining human capital can benefit people in several other ways. Based on research done by Neve and Fink, children's education, which then became a part of their human capital, is associated with their parental old age survival [33]. They found that most parents would benefit from their children's human capital, which then leads to a higher survival rate [33]. There is a higher chance for people to have a stable job with human capital, helping countries reduce the unemployment rate [34]. Moreover, the crime rate comes down when people have more human capital [35]. Decreasing the unemployment rate and crime rate definitely leads to a better life for people. In this case, accumulating human capital can benefit society since it helps solve some problems in society.

Last but not least, human capital would affect individuals' lives and their descendants and parents. Its intergenerational effects would last longer than most people previously expected. In a study done by Adermon and his fellow researchers, the effects placed by human capital lasted for four generations [36]. Therefore, it is more than individuals but generations. As human capital is so important, the importance of education in one's life is self-evident then.

\section{CONCLUSION}

In general, this research paper has shown the result that social reproduction has a long-life effect on K-12 students. Social capital affects student educational achievement, trust and social network. Further analysis showed that Students could use their social capital to create favorable conditions. Students who have better social capital can receive more academic support, and social capital also plays an essential role in academic performance and student future study. Financial capital's effect on the student can be described from three aspects of personal, school, and society. The student personal resource inequality can be influenced by financial capital. From the school side, the amount of financial resources influences the quality of a school. In society, a family with more financial capital means more education opportunities for their students. Education will be a part of our life for the rest of our lives. Inequality in education that results from financial capital will have a long-term impact on a person's K-12 education. Human capital can affect student outcomes, education level when people are in school. After graduating, people's human capital can affect their career success and even the survival rate of parents. The effects of human capital will be intergenerational and it is more than one's life-long effects.

Overall, these three-capital mentioned above all demonstrate the longevity, importance, and inevitability of their impact on people both in the short and long term. Those capitals are inherent in people and are inevitably passed on to future generations. In the education system, even if people have different levels of capital, they can still improve the status quo by attaining education through their own efforts. Therefore, social reproduction inevitably occurs in society and is used to maintain social status and privilege while the power of education can minimize it.

\section{REFERENCES}

[1] M. Reichelt, et al., "School Tracking and Its Role in Social Reproduction: Reinforcing Educational Inheritance and the Direct Effects of Social Origin." The British Journal of Sociology, 2019.

[2] A, Sullivan, et al., "The Path from Social Origins to Top Jobs: Social Reproduction via Education." The British Journal of Sociology, 2017.

[3] J. Collins, "Social Reproduction in Classrooms and Schools." Annual Review of Anthropology, vol. 38, no. 1, 2009.

[4] G. Plagens, Social Capital and Education: Implications for Student and School Performance. Education and Culture, 27(1), 2011, pp. 40-64.

[5] W. Au, Devising Inequality: A Bernsteinian Analysis of High-Stakes Testing and Social Reproduction in Education. British Journal of Sociology of Education, 29(6), 2008, pp. 639-651. 
[6] I.V. Ivanova, Non-formal Education: Investing in Human Capital. Russian Education \& Society, 58(11), 2016, pp.718-731.

[7] M. Ling, "Bad Students Go to Vocational Schools!": Education, Social Reproduction and Migrant Youth in Urban China. The China Journal, (73), 2015, pp.108-131.

[8] J.L. Waters, Geographies of International Education: Mobilities and the Reproduction of Social (Dis)advantage. Geography Compass, 6(3), 2012, pp.123-136.

[9] C. Fearon, S. Nachmias, H. McLaughlin, \& S. Jackson, Personal values, social capital, and higher education student career decidedness: A new 'protean'-informed model. Studies in Higher Education (Dorchester-on-Thames), 43(2), 2018, pp.269-291.

[10] I.R. Yavuz, Founders' education, social capital, and their interplay in the intensity of new-venture internationalization. Journal of Small Business Management, pp.1-37.

[11] J.R. DeLuca, \& D.L, Andrews, Exercising Privilege: The Cyclical Reproduction of Capital through Swim Club Membership. Sociological Inquiry, 86(3), 2016, pp. 301-323.

[12] G.M. Fulkerson, \& G.H. Thompson, The Evolution of a Contested Concept: A Meta-Analysis of Social Capital Definitions and Trends, 78(4), 2008, pp. 536-557.

[13] M, Leaning, Digital divides: Access, skills and participation. Media and Information Literacy, 2017.

[14] R. Raghavan, Practical hr. Human Capital Management Challenges in India, 2014.

[15] P. Kaufman, Middle-Class Social Reproduction: The Activation and Negotiation of Structural Advantages. Sociological Forum, 20(2), 2005, pp. 245-270.

[16] S.J. Ball, The Risks of Social Reproduction: The middle class and education markets. London Review of Education, London review of education, 2003.

[17] E.Y. Tsang, \& P.K. Lee, Raising Successful Offspring by Chinese Middle-Class Parents: A Sociocultural Approach to the Study of Class Reproduction in Urban China. Asian Journal of Social Science, 44(1/2), 2016, pp. 165-186.

[18] C.D. Johnson, Social Capital: Theory, Measurement and Outcomes. Nova Science Publishers, Inc., 2013
[19] P. Mikiewicz, Social capital and education - An attempt to synthesize conceptualization arising from various theoretical origins. Cogent Education, 2021.

[20] W.S. Peter, Stigmatizing Labels, School Bonds, and Capital in the School Reentry Experiences and Educational Outcomes of Justice Involved Youth. VCU University Archives, 2021. pp. 49.

[21] A. Erkan, Effects of Social Capital on Academic Success: A Narrative Synthesis. Educational Research and Reviews, 6 (6), 2011, pp.456-461.

[22] A. Lareau, "Social class differences in family-school relationships: The importance of cultural capital." Sociology of education, 1987, pp. 73-85.

[23] E. Hannum, X. An, and S.H. Cherng, "Examinations and educational opportunity in China: Mobility and bottlenecks for the rural poor." Oxford Review of Education, 37(2), 2011, pp. 267-305.

[24] "What Is Financial Capital? Definition and Its Explanation.” Penpoin. 2020.

[25] S.J. Salloum, R.D. Goddard, \& D. Berebitsky, "Resources, Learning, and Policy: The Relative Effects of Social and Financial Capital on Student Learning in Schools." Journal of Education for Students Placed at Risk, 23(4), 2018, pp. 281-303.

[26] The Reformers: Backed with Political and Financial Capital, Advocates of Change Push to Improve America's Education System. AMERICAN SCHOOL AND UNIVERSITY, 11, 18, 2007.

[27] L. Wantchekon, M. Klasnja, \& N. Novta, Education and human capital externalities. The Quarterly Journal of Economics, 130(2), 2015, pp. 703-757.

[28] N. Angrist, S. Djankov, P.K. Goldberg, \& H.A. Patrinos, Measuring human capital using global learning data. Nature (London), 592(7854), 2021, pp. 403-408.

[29] R.E. Manuelli, \& A. Seshadri, Human capital and the wealth of nations. The American Economic Review, 104(9), 2014, pp. 2736-2762.

[30] H. Li, P. Loyalka, S. Rozelle, \& B. Wu, Human Capital and China's Future Growth. The Journal of Economic Perspectives, 31(1), 2017, pp. 25-47.

[31] B.C. Martin, J.J. McNally, \& M.J. Kay, Examining the formation of human capital in entrepreneurship: A meta-analysis of entrepreneurship education outcomes. Journal of Business Venturing, 28(2), 2013, pp. 211-224.

[32] D. Ucbasaran, P. Westhead, \& M. Wright, Opportunity Identification and Pursuit: Does an 
Entrepreneur's Human Capital Matter? Small Business Economics, 30(2), 2008, pp. 153-173.

[33] J. De Neve, \& G. Fink, Children's education and parental old age survival - Quasi-experimental evidence on the intergenerational effects of human capital investment. Journal of Health Economics, 58, 2018, pp. 76-89.

[34] I. Cairó, \& T. Cajner, Human capital and unemployment dynamics. The Economic Journal (London), 128(609), 2018, pp. 652-682.
[35] L. Lochner, Education, work, and crime. International Economic Review (Philadelphia), 45(3), 2004, pp. 811-843.

[36] A. Adermon, M. Lindahl, \& M. Palme, Dynastic Human Capital, Inequality, and Intergenerational Mobility. The American Economic Review, 111(5), 2021, 1523. 